University of Nebraska - Lincoln

DigitalCommons@University of Nebraska - Lincoln

Faculty Publications: Department of Teaching, Department of Teaching, Learning and Teacher Learning and Teacher Education

Education

January 2004

\title{
Introduction: Examining the Roles and Possible Roles of State Departments of Education in Comprehensive School Reform
}

\author{
Edmund T. Hamann \\ University of Nebraska - Lincoln, ehamann2@unl.edu
}

Follow this and additional works at: https://digitalcommons.unl.edu/teachlearnfacpub

Part of the Teacher Education and Professional Development Commons

\begin{abstract}
Hamann, Edmund T., "Introduction: Examining the Roles and Possible Roles of State Departments of Education in Comprehensive School Reform" (2004). Faculty Publications: Department of Teaching, Learning and Teacher Education. 59.

https://digitalcommons.unl.edu/teachlearnfacpub/59
\end{abstract}

This Article is brought to you for free and open access by the Department of Teaching, Learning and Teacher Education at DigitalCommons@University of Nebraska - Lincoln. It has been accepted for inclusion in Faculty Publications: Department of Teaching, Learning and Teacher Education by an authorized administrator of DigitalCommons@University of Nebraska - Lincoln. 


\title{
Introduction: Examining the Roles and Possible Roles of State Departments of Education in Comprehensive School Reform
}

\author{
Edmund T. Hamann \\ The Education Alliance \\ Brown University
}

Though I have only just realized it, this special issue of Journal of Education for Students Placed at Risk (JESPAR) did not originate at the annual meeting of the American Educational Research Association in April of 2004, where four of the five articles shared here were first presented, although that forum obviously mattered to the creation of this issue. ${ }^{1}$ Rather, this issue began taking shape 14 years ago, in 1990, when, as an undergraduate, I took a seminar with the founder of the Coalition of Essential Schools, Ted Sizer, and his colleague, Rick Lear. At that time, I learned that the Coalition's efforts were playing a modest but real role in the launch of a broader movement - comprehensive school reform (CSR) - that asserted most schools' organizational structures were problematic and in need of a total and systematic overhaul, not just tweaking, changes for some students, or different efforts from some teachers. I also learned of the Coalition's nascent partnership with the Educational Commission of the States (ECS), a project called RE:Learning, that sought to bridge policy and practice. That partnership acknowledged that comprehensive whole-school changes needed to be complemented by changes at some remove from schools themselves. These entailed making changes at the level of state education policy. ECS then (and now) existed to bring together major state-level education policymakers, like governors and education commissioners, to share ideas and strategies for educational improvement.

Requests for reprints should be sent to Edmund T. Hamann, The Education Alliance at Brown University, 222 Richmond Street, Suite 300, Providence, RI 02903-4226. E-mail: Edmund_Hamann@brown.edu

${ }^{1}$ The session at the American Educational Research Association annual meeting in San Diego was called "Changing Single Schools And/Or Changing Systems: The Role of State Departments of Education in Comprehensive School Reform." The author served as the session organizer. 
In the ensuing years, the RE:Learning initiative has largely disappeared, though both ECS and the Coalition continue to prosper. A June 2004 Google search for "RE:Learning + school" turned up 150 hits, but only two referenced the Coalition/ECS partnership, the newer one dating from 1995. However, the diagnosis of the problems facing schools and states that informed the RE:Learning partnership has remained salient, perhaps becoming even more crucial as the CSR movement has become more successful and state departments of education (also known as state education agencies [SEAs]) have become more substantial partners in its implementation. Both the Improving America's Schools Act of 1994 and its successor, the No Child Left Behind Act of 2001, substantially expanded the number of Title I Schoolwide schools (a program that had been initiated at a small scale in 1988), thus expanding the number of schools given federal resources for involving all staff in making improvement for all students. The Obey-Porter Comprehensive School Reform Demonstration (CSRD) program, launched in 1997, was even more direct in its emphasis on CSR. All of these initiatives have positioned SEAs as key policy intermediaries (Hamann \& Lane, 2004), as SEAs manage how federal resources are disseminated to districts and schools. For these and many other reasons, the roles of SEAs in relation to CSR have become multiple, complex, and sometimes contradictory: SEAs act as promoters, managers, supervisors, initiators, intermediaries, fiduciary agents, and more.

Billions of dollars are invested annually in schools using CSR as a core strategy for improving low-performing schools and achieving equitable education (Berman \& Chambliss, 2000). With SEAs as key participants in the CSR implementation process, examining the relation between SEAs and CSR is of utmost importance. Yet the relationship between SEAs and CSR's viability and implementation has been little scrutinized beyond claims like those made by Borman (2002), who noted that "it seems most states lack the capacity to assist Title I schools in need of reform and improvement" (p. 236). This lack persists despite calls for studies of state contexts and CSR at such recent events as the Cross-Laboratory CSRD Research Meeting (held on April 6, 1999, a gathering of the 10 federally funded regional educational laboratories) and the National Clearinghouse on Comprehensive School Reform's Network of Researchers meeting (May 21-22,2002). The five articles and one commentary presented in this special issue of JESPAR intend to redress this paucity, while examining more than just SEA roles in shaping context. The understanding in these articles is that SEAs are actors in CSR implementation (Hamann \& Lane, 2004).

The articles collected here consider the role of SEAs in relation to two emerging criticisms of the CSR movement: (a) that the school restructuring and improvement sought by the movement are vulnerable without complementary systemic reforms and (b) that, like previous waves of A Nation At Risk-inspired school reform, the CSR movement is failing to impact teaching and learning (Sack, 2002; Viadero, 2001). The articles in this journal are all informed by three themes. First, SEAs recently have been called on to play more roles, accomplish more tasks, and 
generally shift their modes of operation away from traditional, hierarchical, bureaucratic models to that of more nimble, laterally oriented learning organizations (Lusi, 1997). Second, this changed role for SEAs is being pursued the same time as an ongoing process of SEA downsizing and budget crises that has been occurring intermittently since the Reagan administration began reducing federal support to SEAs (Institute for Educational Leadership, 2001). Third, the CSR movement has gained momentum at the same time as (but not always aligned with) some systemic education reform efforts, such as the standards movement and the related high-stakes accountability movement (see Datnow, this issue).

For our purposes, CSR in these articles refers both to the specific federal Comprehensive School Reform program (i.e., Obey-Porter and CSRD) and, more generally, to the movement for whole-school reform as a replacement for more piecemeal education reform strategies. The authors in this issue clarify when they are using the term holistically, when it refers to the federal program, or, in the case of Erlichson's article, when it denotes a key strategy in New Jersey's work with its Abbott districts. As Desimone (2002) defined it in her thorough review, the third wave of post-A Nation At Risk school reform (CSR) refers to "a popular approach to school improvement [that] is intended to foster schoolwide change that affects all aspects of schooling (e.g., curriculum, instruction, organization, professional development, and parent involvement)" (p. 433). Often, but not always, CSR has included the importation of externally developed school reform models.

Both Obey-Porter and the more general CSR movement can trace their origins, at least partly, to the series of Elementary and Secondary Education Acts (ESEAs), including the original act of 1965, which in turn were policy responses to the Brown $v$. Topeka Board of Education decision of 1954, but they depart from the theory of action of those initial ESEAs. To adequately contextualize the current critique of the CSR movement (a critique the following articles sometimes contribute to), it is useful to first understand the criticisms of previous reform efforts that led to the CSR movement. As the frequent use of the term compensatory education suggests and as the language of the first ESEA in 1965 actually reads- " [this program is] to provide financial assistance to ... contribute particularly to meeting the special educational needs of educationally deprived children" (quoted in Borman, 2002, p. 232) - the early ESEAs did not originally include a critique of schooling per se. Rather, their operating rationale seemed to be that schooling is generally fine, but some kids are needier and suffer from inadequate access to resources. Compensatory supplementations would remedy the school problems these children faced.

That perspective differs significantly from the perspectives that emerged in the late 1970s as part of the Effective Schools movement (Cuban, 1998) and in the early 1980s from only loosely related efforts like the Study of High Schools (Sizer, 1984; Powell, Farrar, \& Cohen, 1985). These, in turn, launched the previously mentioned Coalition of Essential Schools. In the face of a conservative critique that poverty inevitably led to poor student outcomes, the Effective Schools move- 
ment responded that research showed that some schools serving low-income students were substantially more successful than others. How schools were organized and what schools did could substantively and favorably affect students' achievement, so the need was to identify what it was about those schools, as compared to others, that made them work. The school, not a compensatory education teacher within the school, was presumed as the unit of treatment.

Participants in the Study of High Schools also argued that prior school improvement efforts had been less successful than they could have been because they had not envisioned the whole school as a unit of change. In The Shopping Mall High School, Powell et al. (1985) complained about the sprawling, uncoordinated aggregation of programs that typified most comprehensive high schools, explaining that each appended program might have a specific rationale, but that its combination with other programs led to an unaligned, poorly coordinated, inadequate whole. This critique was used to argue for coordinated, whole-school strategies in which change processes involved all or nearly all students and staff, and program steps were to be explicitly coordinated with each other.

Thus the emerging wisdom of 1985, as compared to 1965, highlighted the value of targeting whole schools as the unit of change rather than assuming schools and their existing structures were generally fine, needing only a few special programs for a handful of "don't fit" students (Deschenes, Cuban, \& Tyack, 2001). The school as unit of change rationale supported the launch of the aforementioned Coalition of Essential Schools in 1984 and, more generally, became the core grounding for the CSR movement that followed. Since then, the education reform community has seen the rise of the New American Schools initiative (Berends, Bodilly, \& Kirby, 2002), the 1994 ESEA reauthorization (the Improving America's Schools Act), and the 1997 Obey-Porter Comprehensive School Reform Demonstration program (renamed the Comprehensive School Reform program in 2001). Yet even as the CSR movement gained ascendancy, it also encountered increasing skepticism, as it has not proven as transformative at a large scale as its proponents had hoped.

In a case study of an "innovative" school in Canada, Fink (2000) offered one explanation for a core challenge faced by CSR schools; absent changes in the norms and expectations of the surrounding system, innovative schools are constantly buffeted by pressures to become more normal (i.e., less innovative). Staying out of equilibrium with the status quo requires high expenditures of energy and the persistent confidence of educators. Any stumble by the school can be used to critique its difference. The experiences of the High Performing Learning Community Project and other long-time promoters of whole-school transformation point to similar conclusions: Improvement at a single school can be both profound and ephemeral. Coordinating and synchronizing the efforts of all educators in a building can have a profound and powerful favorable effect on student achievement (Borman, Hewes, Overman, \& Brown, 2003), but such effects can prove ephemeral because change efforts often founder when there is a change in leadership or a new and displacing 
policy mandate from the district or state. The bigger task, then, is to figure out how school-by-school whole-school reform can lead to enduring improvement. As Datnow, Hubbard, and Mehan (2002) and Berman and Chambliss (2000) recently investigated, can the actions and strategies of a successful school be replicated elsewhere? Does such a strategy make CSR systemic? What can make CSR systemic? According to Lusi (1997):

States are engaged in complex school reform to improve the academic achievement of students in all schools. Improving student achievement, however, requires changing the behavior of teachers. The problem presented by complex school reform, then, is the problem of how the [SEA] can bring about specified changes in the practice of a large number of practitioners over whom it has little, if any, direct control and to whom it has no proximity. (p. 10)

We must ask whether and in what conditions SEAs might be vehicles for converting the gains of individual comprehensively reforming schools into something more systemic. Conversely, we also want to know when and how SEAs miss or fall short of the opportunity for such a conversion. Lusi (1997) was not only (or even mainly) referring to CSR with her comment about "complex school reform"; another point of departure for the authors in this special issue of JESPAR is to consider how CSR competes with other reform ideas in both school and SEA settings.

This issue brings together an interdisciplinary team of education scholars (representing sociology, applied linguistics, political science, psychology, evaluation, and anthropology) who have each been involved in studying one or more state's efforts to implement CSR. The heterogeneity of research perspectives is an intended asset of this issue, as different disciplines consider the interface between educational policy (CSR policy) and practice differently. Michael Knapp (2002), policy implementation researcher and director of the Center for the Study of Teaching and Policy at the University of Washington's College of Education, recently wrote:

Frameworks that treat the [educational] policy as a discrete traceable set of resources, requirements, and reform intentions emanating from an "outside" source tend to lose sight of the way actors at each level of the system interpret and make use of policy events to achieve their own purposes. Frameworks that focus on the fine detail of teachers' or other professionals' practice "on the inside" tend to underestimate the way larger environmental factors guide, constrain, or permeate teachers' action and thinking or the results of their efforts. (p. 6)

It is my hope that the following articles juxtapose "inside" and "outside" perspectives.

Because of the geographic spread of the cases considered here, this issue also supports a juxtaposition of small states with large states, rural states with mostly 
urban states, and the Northeast region with the South and Southwest. Thus, by triangulating both disciplinary perspectives and contextually varied cases, some larger generalizations emerge-notably that the stance taken by various SEAs to CSR has varied substantially, with Arizona and California doing hardly more than organizing the dissemination of resources (and even then somewhat begrudgingly), whereas New Jersey and Maine have promoted CSR as a core education strategy. Collectively, the articles consider SEAs' roles in CSR in Arizona, California, Connecticut, Florida, Maine, Massachusetts, New Hampshire, New Jersey, New York, Rhode Island, Texas, and Vermont.

The first article of the five in this special issue was written by Bari Anhalt Erlichson, who for more than 5 years has been studying New Jersey's use of CSR as a core strategy for responding to New Jersey State Supreme Court orders that the state do more to support school improvement in the state's 30 urban Abbott districts. Her article, "Comprehensive School Reform in New Jersey: Waxing and Waning Support for Model Implementation," differs from the others in this issue because the federal Obey-Porter CSR program is not its point of departure. Nonetheless, the New Jersey case is a good place for this issue to start because it represents one of the most complex and substantive state-level implementations of CSR, as well as one of the most visible examples of how that implementation has proven vulnerable to competing policy currents and political impatience for improvement. Erlichson's article highlights the inherent complexity of implementing CSR as a systemic reform, a complexity that belies the rather straightforward problem diagnoses that ground the movement. New Jersey's Abbott schools have been both buffeted and supported by four external constituencies: (a) the state courts as originators of the Abbott mandate, (b) the New Jersey Department of Education (NJDOE) as the key intermediary for how the court mandate is to be interpreted into educational policy, (c) the NJDOE field agents (who are not based in Trenton, who interact much more frequently with the schools, and who are viewed as separate from bureaucrats in the state capital), and (d) the CSR model developers. For reasons more grounded in political sensibilities than research, New Jersey began moving away from the twinning of CSR and Abbott in 2003.

Though Arizona's implementation of Obey-Porter bears little resemblance to New Jersey's experience with Abbott, Good and McCaslin's article almost reads as a collective sigh of relief on the part of principals at Arizona's CSR schools; that they do not have to deal as much with SEA intervention as their CSR colleagues have had to in other states. Derived from their larger ongoing study of the leadership challenges for principals guiding whole-school change, the main sources of data for Good and McCaslin's "CSR Principal Perceptions of Support from the State Department of Education" are principals' comments on their relationship, or lack thereof, with the Arizona Department of Education (ADE) regarding the CSR program. In most cases, the ADE/CSR school relationship has constituted not more than the minimal routine contact necessary for the distribution of funding. The Good and 
McCaslin article is a useful reminder of the skepticism that characterizes schools' responses to possible involvement by their SEA. If, as Lusi (1997), the task force on state leadership of the Institute for Educational Leadership (2001), and the organizers of RE:Learning all believed, the role of SEAs in school improvement needs to grow and change, then this skepticism on the part of principals raises an important cautionary flag about how such efforts are likely to be received.

For different reasons and with different mechanisms, the article titled "English Language Learners, Comprehensive School Reform, and State Education Agencies: An Overlooked Opportunity to Make Comprehensive School Reform Comprehensive" echoes the Arizona principals' doubts about SEAs' willingness and capacity to engage with schools in helping to transform domains where schools have traditionally struggled. This article, which I co-authored with Ivana Zuliani and Matthew Hudak, suggests that seven northeastern SEAs failed to identify the existing dichotomy between CSR and school responsiveness to English Language Learners (ELLs) and thus did not ensure that CSR was responsive to the research on meeting the needs of all students. The article also notes that the first cohorts of Obey-Porter CSR schools in these states had a disproportionately high enrollment of ELLs. SEAs were not the cause of this problem, but they missed a chance to be its remedy.

If the first three articles emphasize what the SEAs struggled to do or did not do (sometimes to the relief of schools) with CSR, the article by Brett Lane and Susan Gracia serves as a useful corrective, noting what the same seven states studied in the article by Hamann, Zuliani, and Hudak did do in regard to CSR. Lane and Gracia's article, "State-Level Support for Comprehensive School Reform: Implications for Policy and Practice," notes how states that bordered each other and shared ideas with each other nonetheless approached CSR implementation quite differently, making awards of dramatically different sizes, for example, or actively tying CSR implementation to the implementation of state-initiated reform frameworks. Lane and Gracia's article reminds us that the negotiation of CSR and systemic reform is no less complex from the SEA perspective than from that of schools or model developers. As with the changes and challenges experienced by school personnel, CSR reform as enacted from an SEA is equally dependent on the learning, vision, and action of involved personnel, personnel who often have to reconcile CSR oversight with other tasks.

Datnow's article, "Happy Marriage or Uneasy Alliance? The Relationship Between Comprehensive School Reform and State Accountability Systems," anchors the issue, juxtaposing accounts of SEAs' oversight of CSR in three of the largest states-California, Florida, and Texas-with the ways CSR was experienced at a selected school in each of these states. Her article demonstrates how powerful SEA directives were in shaping the contexts of schooling in each of the three sites, but also illustrates how CSR was far from the most powerful manifestation of state support and state mandates at each school. Invariably, the pressure of other man- 
dates and high-stakes assessments demanded greater effort, attention, and investments of schools' time. The less demanding recommendations of model developers could not compete with these pressures, and SEAs did not or could not intervene to safeguard the concept of CSR at these schools. Perhaps this is the most powerful story Datnow's case studies tell. In their management of programs and negotiation of federal and SEA-initiated directives, SEAs have been willing to implement CSR, but not as a first priority and not necessarily in ways that ensure that its core premises are protected from the onslaught of other recommendations and requirements that schools must accommodate.

Hugh Mehan concludes the issue by offering summative comments on each of the five articles and highlighting several themes tying them together. He agrees that the roles of SEAs are changing, but sees that the SEAs' potential to be more hands-on, dependable, and usefully involved in CSR has thus far been substantially underrealized. Many more possible roles for SEAs exist than have been acted on. He critiques the articles for not further exploring why there seems to be so frequent a disconnect between CSR policy and practice; in so doing, Mehan outlines one key domain in which future inquiry should be directed.

Given the empirical record shared here of SEAs being important players in the CSR implementation process, but frequently not as a "value-added" (although there are exceptions), there needs to be further investigation regarding why this is so. Mehan calls for further explication of the intriguing relations between state mandates, school-site practicalities, and opportunistic actions. Although not directly addressing CSR, Spillane (2001) outlined one facet of needed inquiry with his emphasis on considering the cognition of those involved in policy implementation, including those at SEAs. Brett Lane and I (Hamann \& Lane, 2004) tried to outline some of that terrain with our depiction of SEA personnel in Maine and Puerto Rico as policy intermediaries.

Still, understanding more clearly why the status quo is what it is can only be part of what happens next. We need to understand what assumptions would need to be adopted by SEA personnel and others, what knowledge would need to be acquired by SEA personnel and others, and what resource flows to SEAs and elsewhere would be needed to change the conditions these articles document. Here, again, I find my mind drifting back to my undergraduate days in Ted Sizer's seminar: What would it have taken to make RE:Learning work? This is an historical question, but one with urgent contemporary relevance.

\section{ACKNOWLEDGMENTS}

While as guest editor of this issue I need to be ultimately responsible for its limitations, credit for its successes needs to be generously shared. First, thanks should be directed to JESPAR editor Sam Stringfield for his willingness to devote an entire 
issue to this important topic. Also, in addition to thanking each of the authors for their intellectual contributions, I want to praise them all for the promptness with which they converted a late April 2004 invitation to create this issue into a viable response. All articles were submitted in final version by the end of June. As a final and loudest thank you, I want to acknowledge JESPAR's Managing Editor, Kirsten Sundell, who proved to be not only a highly capable editor, but an extraordinarily prompt one. She has been a pleasure to collaborate with.

\section{REFERENCES}

Berends, M., Bodilly, S., \& Kirby, S. (2002). Facing the challenges of whole-school reform: New American schools after a decade. Santa Monica, CA: Rand.

Berman, P., \& Chambliss, D. (2000). Readiness of low-performing schools for comprehensive reform. Emeryville, CA: RPP International.

Borman, G. (2002). Title I: The evolution and effectiveness of compensatory education. In S. Stringfield \& D. Land (Eds.), Educating at-riskstudents (pp. 231-247). Chicago: University of Chicago Press.

Borman, G., Hewes, G., Overman, L., \& Brown, S. (2003). Comprehensive school reform and achievement: A meta-analysis. Review of Educational Research 73, 125-230.

Cuban, L. (1998). How schools change reforms: Redefining reform success and failure. Teachers College Record, 99, 453-477.

Datnow, A., Hubbard, L., \& Mehan H. (2002). Extending educational reform: From one school to many. London: RoutledgeFalmer.

Deschenes, S., Cuban, L., \& Tyack, D. (2001). Mismatch: Historical perspectives on schools and students who don't fit them. Teachers College Record, 103, 525-547.

Desimone, L. (2002). How can school reform models be successfully implemented? Review of Educational Research, 72, 433-479.

Fink, D. (2000). Good schools/real schools: Why school reform doesn't last. New York: Teachers College Press.

Hamann, E., \& Lane, B. (2004). The roles of state departments of education as policy intermediaries: Two cases. Educational Policy, 18, 426-455.

Institute for Educational Leadership (2001). Leadership for student learning: Recognizing the state's role in public education. Washington, DC: Author.

Knapp, M. S. (2002). Understanding how policy meets practice: Two takes on local responses to a state reform initiative. Seattle, WA: Center for the Study of Teaching and Policy, University of Washington.

Lusi, S. F. (1997). The role of state departments of education in complex school reform. New York: Teachers College Press.

Powell, A., Farrar, E., \& Cohen, D. K. (1985). The shopping mall high school: Winners and losers in the educational marketplace. Boston: Houghton Mifflin.

Sack, J. (2002, January 30). Experts debate effect of whole-school reform. Education Week, 21(20), 6.

Sizer, T. (1984). Horace's compromise: The dilemma of the American high school. Boston: Houghton Mifflin.

Spillane, J. (2001). Challenging instruction for "all students": Policy, practitioners, and practice. In S. Fuhrman (Ed.), From the capitol to the classroom: Standards-based reform in states (pp. 217-241). Chicago: University of Chicago Press.

Viadero, D. (2001, November 7). Whole-school projects show mixed results. Education Week, 21(10), 1, 24-25. 